\title{
РОЗВИТОК МЕТОДИКИ ВИЯВЛЕННЯ І ОЦІНКИ РЕГІОНАЛЬНИХ КОНКУРЕНТНИХ ПЕРЕВАГ
}

\section{DEVELOPMENT OF METHODS OF DETECTION AND EVALUATION OF REGIONAL COMPETITIVE ADVANTAGES}

\author{
Нестеренко Світлана Сергіївна \\ кандидат економічних наук, доцент, \\ Відкритий міжнародний університету розвитку людини «Україна» \\ ORCID: http://orcid.org/0000-0001-9090-3470 \\ Nesterenko Svetlana \\ Open International University of Human Development "Ukraine"
}

\begin{abstract}
Стаття розглядає актуальне питання розвитку методики виявлення і оцінки регіональних конкурентних переваг в масштабі національної економіки. Було показано, що рівень регіональної конкурентоспроможності слід визначати в координатах потенціалу розширеного відтворення і динамічного приросту мезоекономічних показників. Визначено, що цільовим вектором формування регіональних конкурентних переваг повинен бути показник якості життя населення регіону. Було проведено аналіз методичних підходів оцінки регіональних конкурентних переваг, за результатами якого був розроблений авторський методичний підхід, в якому виділено комплексний показник оцінки конкурентоспроможності регіону, що формується 3 першого показника оцінки поточного рівня життя населення регіону, що включає в себе локальні індекси виробничо-економічного і демографрічного походження. Другим показником виступає інтегральний показник оцінки загальної соціально-економічної привабливості регіону, в якому провідні позиції займають інвестиційні оцінки.

Ключові слова: регіональні конкурентні переваги, національна економіка, рангова оцінка, рівень життя, інвестиційна привабливість, економічне зростання.

Статья рассматривает актуальный вопрос развития методики выявления и оценки региональных конкурентных преимуществ в масштабе национальной экономики. Было показано, что уровень региональной конкурентоспособности следует определять в координатах потенциала расширенного воспроизводства и динамического прироста мезоэкономических показателей. Определено, что целевым вектором фрормирования региональных конкурентных преимуществ должен быть показатель качества жизни населения региона. Был проведен анализ методических подходов оценки региональных конкурентных преимуществ, за результатами которого был разработан авторский методический подход, в котором выделен комплексный показатель оценки конкурентоспособности региона, формирующийся из первого показателя оценки текущего уровня жизни населения региона, включающий в себя локальные индексы производственно-экономического и демографического происхождения. Вторым показателем выступает интегральный показатель оценки общей социальноэкономической привлекательности региона, в котором ведущие позиции занимают инвестиционные оценки.

Ключевые слова: региональные конкурентные преимущества, национальная экономика, ранговая оценка, уровень жизни, инвестиционная привлекательность, экономический рост.
\end{abstract}

The article examines the scientific issues of the development of methods for identifying and further assessing regional competitive advantages. It was shown that the competitiveness of a region is defined as the ability to create conditions for sustainable development of the region, expressed through the level (quality) of life of the population and the efficiency of using available resources in a free and fair market. The analysis of methods for assessing the competitiveness of a region made it possible to propose an approach according to which a comprehensive indicator of a region's competitiveness is made up of two components: indicators of the standard of living (index of human development in the region; Gini coefficient; unemployment rate; provision of housing; provision of population with doctors) and indicators of the region's attractiveness for business (investment potential of the region; investment risk; real investment volumes; number of unprofitable enterprises in the region). The assessment is based on the ranking of regions according to the numerical values of each of the particular indicators with the determination of the corresponding place in the region. The calculation of the integral indicator is carried out in stages by implementing the following sequence of actions. At the first stage, for each of the assessment indicators, the rank of each region is determined, starting with the best value (first place) and ending with the worst value (last place). Then the obtained ranks are summed up and the integrated ranks are determined according to the indicator 
of the standard of living of the population and the indicator of the attractiveness of the region for business. In the event that for any indicator there are absolutely identical values for two or more regions, then the operation of local ranking of these regions is performed in accordance with the values of the key indicator - the volume of gross regional product, taking into account the level of purchasing power per capita for the indicator of attractiveness region for business and life expectancy for the indicator of living standards of the population. The region with the lowest score is considered more competitive.

Keywords: regional competitive advantages, national economy, rank assessment, standard of living, investment attractiveness, economic growth.

Постановка проблеми. Господарська модель регіону в рамках національної економіки має складну галузеву і територіальну структуру, в той же час, економіці регіону властива внутрішня господарська цілісність і комплексність. Вона означає раціональне використання ресурсного потенціалу регіону, пропорційне поєднання різних галузей, срормування стійких внутрішньорегіональних і міжрегіональних виробничих і технологічних зв'язків, наявність особливого співтовариства людей 3 певними традиціями і способом життя.

Під регіональною комплексністю слід розуміти певний фрормат інтеграції, що забезпечує розвиток регіональних продуктивних сил на основі нівелювання внутрішньогосподарських диспропорцій і збереження потенціалу самостійної реалізації функції розширеного виробництва, широко використовуючи арсенал регіональних природніх та економічних ресурсів. Фактор регіональної комплексності має проявитися в обґрунтованому поєднанні виробничих ссрер та регіональної інсрраструктури, які і формують сталу основу економіки регіону. Ці компоненти визначають актуальність і перспективність досліджень в напрямку розвитку методик оцінки регіональних конкурентних переваг 3 метою подальшого підвищення якості регіонального управління для досягнення стратегічних цілей мезоекономічного рівня.

Аналіз останніх досліджень і публікацій. Теоретичною і методологічною основою цього дослідження послужили праці вітчизняних і зарубіжних учених: О. Бобровської, Р. Бошма, С. Захарченко, Н. Павліхи, М. Перрі, І. Польської, О. Романко, Дж. Роуї, Т. Савостенко, І. Турка, які зробили суттєвий істотний внесок у розуміння динаміки набуття конкурентоспроможності на регіональному рівні в межах економіки країни. Разом з тим ряд принципових положень щодо фрормування і методичного забезпечення оцінки регіональних конкурентних переваг, особливо на макроекономічному рівні, залишаються відкритими.

Формулювання цілей статті (постановка завдання). Мета дослідження - аналітичне обґрунтування діючих показників і методик оцінки регіональних конкурентних переваг, та розробка авторського методичного підходу для комплексного проведення такої оцінки.

Виклад основного матеріалу. Для управління економічними процесами на регіональному рівні велике значення має оцінка конкурентних позицій регіонів. Однак, зміст економічної моделі регіональних конкурентних переваг свідчить про складному і багатофракторний характер її складових, що не дозволяє виділити якийсь один найсуттєвіший показник, в повній мірі характеризує розвиток території. Виникає необхідність оцінки різних аспектів господарської діяльності регіону та пошуку комплексного критерію конкурентоспроможності. В науковій літературі в даний час існує декілька підходів до визначення інтегральних показників розвитку і оцінки конкурентних позицій регіонів, які будуються в основному на оцінці економічних умов регіонів та відповідних можливостей виробництва конкурентоспроможної продукції.

Ряд авторів вважає науково обґрунтованою оцінку конкурентних позицій за реальними значеннями, що відображає економічну ситуацію в регіоні. Так, наприклад, Павліха Н.В. вважає більш прийнятним проводити оцінювання конкурентних позицій за реальними статистичними показниками, що відображають фрактичну ситуацію в регіоні [6]. Аналогічної думки дотримується і Турок I. [8, с. 1064-1065], який пропонує структурний набір, за яким може бути визначена конкурентоспроможність регіону за даними загальнонаціональної статистики. В межах цього підходу можна проводити оцінку рівня конкурентоспроможності регіонів України за ранговим методом, в якому виділені групи структурних мікропоказників, що характеризують певні соціально-економічні фрактори стану справ в регіоні (табл. 1).

Виділяючи провідні підходи і моделі оцінки регіональних конкурентних переваг, звернемо увагу на наукову роботи Р. Бошми, в якій виокремлюється модель розрахунку зведеного інтегрального показника оцінки рівня конкурентоспроможності територій (виділені економічні території) на базі офріційного статистичного потоку [2, с. 1009-1010]:

$$
S_{j}=\sum_{i=1}^{n} \frac{K_{i j}^{p}}{K_{c e p}^{p}} \times 100+\sum_{i=1}^{n} \frac{K_{i j}^{m}}{K_{c e p}^{k}} \times 100
$$


Таблиця 1

Показники рангової оцінки регіональних конкурентних переваг

\begin{tabular}{|c|c|c|c|}
\hline Показники & $\begin{array}{c}\text { Одиниця } \\
\text { вимірювання }\end{array}$ & $\begin{array}{c}\text { Абсолютне } \\
\text { значення } \\
\text { показника } \\
\end{array}$ & $\begin{array}{l}\text { Ранговий } \\
\text { показник }\end{array}$ \\
\hline \multicolumn{4}{|c|}{ Економічні характеристики } \\
\hline Загальна площа регіону & тис. кВ. М. & & \\
\hline Чисельність населення регіону & тис. чол. & & \\
\hline Щільність населення & тис. чол. / кВ. Км & & \\
\hline Обсяг ВРП & тис. грн. грн. / 1 чол. & & \\
\hline Кількість ФОПів & тис. од. & & \\
\hline Кількість фрермерських господарств & тис. од. & & \\
\hline $\begin{array}{l}\text { Індекс регіонального промислового } \\
\text { виробництва }\end{array}$ & $\begin{array}{c}\text { середньорічне } \\
\text { значення, t }\end{array}$ & & \\
\hline Обсяг інвестицій в основний капітал & млн грн. /1 тис. чол. & & \\
\hline Обсяг прямих іноземних інвестицій & $\begin{array}{l}\text { тис. дол. США / } \\
1 \text { тис. чол. }\end{array}$ & & \\
\hline \multicolumn{4}{|c|}{ Соціальні характеристики } \\
\hline Забезпеченість населення житлом & кв. м./ 1 мешканця & & \\
\hline Забезпеченість населення лікарями & $\begin{array}{l}1 \text { лікар/ } 1000 \text { чол. } \\
\text { населення }\end{array}$ & & \\
\hline Забезпеченість населення койко-місцями & $\begin{array}{c}100 \text { койко-місць / } \\
1 \text { тис. чол. населення }\end{array}$ & & \\
\hline \multicolumn{4}{|c|}{ Рівень доходів і заощаджень населення } \\
\hline $\begin{array}{l}\text { Обсяг грошових доходів населення } \\
\text { (середні) }\end{array}$ & грн./мic. & & \\
\hline Розмір заробітних плат (номінальна) & грн./Mic. & & \\
\hline Розмір пенсій (з урахуванням компенсації) & грн./міс. & & \\
\hline Прожитковий мінімум (середній) & грн./міс. & & \\
\hline $\begin{array}{l}\text { Чисельність населення з грошовими доходами } \\
\text { нижче величини прожиткового мінімуму }\end{array}$ & $\%$ & & \\
\hline \multicolumn{4}{|c|}{ Структури використання грошових доходів } \\
\hline $\begin{array}{l}\text { Приріст/зменшення заощаджень } \\
\text { домогосподарств }\end{array}$ & $\%$ & & \\
\hline Обсяг операцій з валютою & $\%$ & & \\
\hline $\begin{array}{l}\text { Рівень зростання реальних доходів } \\
\text { над витратами }\end{array}$ & $\%$ & & \\
\hline
\end{tabular}

Джерело: складено за даними [1; 6; 8]

де $S_{j}$ - зведена інтегральна оцінка рівня конкурентоспроможності регіону;

$K_{i j}^{p}$ - значення $i$-го фрактора в $j$-му регіоні, що визначає спроможність регіону виробляти конкурентоспроможності товари і послуги;

$K_{c e p}^{p}-$ середньонаціональне значення фрактора спроможності регіону виробляти конкурентоспроможності товари і послуги;

$K_{i j}^{m}$ - значення $i$-го фрактора $j$-го регіону, яке визначає рівень якості життя населення;

$K_{c e p}^{k}$ - середньонаціональне значення фракторів оцінки рівня якості життя населення;

$n, k$ - кількість обраних фракторів оцінки;

$i$ - номер фрактора;

$j$-номер обраного регіону.
Для визначення базових параметрів, щодо орормування виробничого потенціалу регіону, 3 метою проведення порівнянь, пропонується визначати ряд таких показників як: 1) ВРП (валовий регіональний продукт), тис. грн./чол.; 2) продуктивність праці, тис. грн./чол.; 3) індекс срізичного обсягу ВРП, \%; 4) обсяг промислового виробництва на 1 чол., тис. грн./чол.; 5) відношення обсягу капітальних інвестицій до обсягу ВРП,\%; 6) знос основних виробничих срондів, \%; 7) експортна квота (відношення експорту до імпорту продукції, \%); 8) срондовіддача; 9) регіональний рівень фрактичного безробіття, \%; 10) обсяг соціальних трансорертів у загальних витратах регіонального бюджету, \% [1]. 
Для визначення базових параметрів щодо здатностірегіонузадовольнятисоціальніпотреби та визначати демограсрічні маркери населення, ми виділимо наступні показники: 1) гендерна тривалість життя, років; 2) площа житлових приміщень на 1 чол., кв. м/чол.; 3) кількість медичних працівників на 1 тис. чол. населення, чол.; 4) частка населення регіону з доходами нижче прожиткового мінімуму, \%; 5) середній розмір пенсій щодо величини прожиткового мінімуму пенсіонерів,\%; 6) середній розмір банківських депозитів до величини прожиткового мінімуму, $\%$; 7) обсяг автономного споживання домогосподарств, млн. грн.; 8) індекс споживчих цін,\% [5].

3 метою врахування територіальної дисреренціації рівня цін в методиці використаємо індикатори, що відображають географрічні особливості країни:

- коефіцієнт рівня купівельної спроможності розраховується як відношення середнього регіонального розміру прожиткового мінімуму до загальнонаціонального значення;

- регіональний коефіцієнт рівня удорожчання капітальних витрат.

Разом з тим заначимо, що методи, які фрормуються тільки на статистичній інформації, мають, на наш погляд, суттєвий недолік - неможливість оцінювати сумарний потенціал розвитку національної економіки країни. Оцінка результату, досягнутого регіоном в останній звітний період, це ще не остаточна оцінка потенціалу регіону. Конкурентоспроможність регіону - це здатність до сталого розвитку, а не матеріалізований результат її застосування. Так не у всіх досягнутих результатах в явному вигляді матеріалізується потенціал регіону. Він може розподілятися неявним чином на всі види продукції, що виробляються, але безпосередньо не знаходитися в їхній собівартості. Таким чином, поняття конкурентоспроможності $€$ більш розлогим за поняття соціально-економічного становища регіону, оскільки передбачає крім оцінки сучасного стану економіки регіону, також і визначення потенціалу розвитку.

В той же час, з точки зору застосування експертної оцінки у визначенні конкурентних позицій регіону цікавим є підхід такого вченого, як Романко О.П. Автором пропонується оцінювати виробничо-економічний стан регіонів за такими позиціями [3]:

- показники, що характеризують місце регіону в територіальному поділі праці країни;

- показники за темпами і пропорціями розвитку економіки регіону;

- інфрормація про ресурсний потенціал і готовність його до практичного використання;
- інфрормація про демограсрічні процеси і їх вплив на економічний і соціальний розвиток регіону;

- інфоормація, що характеризує рівень виробничого потенціалу і його відповідність поточним економічним умовам;

- інсрормація, що характеризує науковотехнічний прогрес в сорерах національної економіки з урахуванням регіональної специфріки.

За кожною із зазначених позицій пропонується надавати оперативну експертну оцінку. Показником якісної оцінки розвитку регіону, може служити економія використаних ресурсів відтворення на одиницю виробленої чистої продукції і підвищення продуктивності праці. Серед недоліків даного підходу, на нашу думку, слід відзначити підвищену увагу до виробничого та ресурсного потенціалу при недостатньому врахуванні соціальної складової регіонального розвитку.

Як зазначалося раніше, регіональні конкурентні переваги - це здатність створювати умови для сталого розвитку регіону, виражена через рівень (якість) життя населення і ефрективність використання наявних ресурсів. Виходячи 3 цього, у визначенні регіональних конкурентних переваг, на наш погляд, доцільно виділити два змістовні блоки: 1) спроможність певного регіону створювати необхідні умови для ведення ефрективної виробничої діяльності в актуальних умовах регіональної конкуренції; 2) базовий потенціал регіону у самозадоволенні потреб власного населення.

Взаємозв'язок зазначених блоків та рівень взаємної інтеграції фрормують нову модель для визначення загальних регіональних конкурентних переваг, яку розрахунково ми представляємо у такому вираженні:

$$
K_{s}=P_{p}+P_{d}
$$

де $K_{s}$ - показник загальної конкурентоспроможності регіону;

$P_{p}-$ оціночний показник привабливості регіону для проживання;

$P_{d}$ - оціночний показник привабливості регіону для товаровиробників і інвесторів.

Зважаючи на вищевикладене, ми вважаємо, що найбільш близькою до авторського розуміння регіональної конкурентоспроможності $€$ методика оцінки регіональних конкурентних переваг, в якій комплексний показник визначення регіональних конкурентних переваг фрормується з показників оцінки рівня життя (E) та оцінки рівня інвестиційної привабливості певного регіону (I) в межах національної економіки країни [4]:

$$
E=C_{a}+G+U_{l}
$$


де $C_{a}$ - рівень реальної купівельної спроможності населення регіону;

$G$ - коефріцієнт Джині (якість доходів);

$U_{l}$ - рівень регіонального безробіття.

3 іншого боку:

$$
I=I_{p}+I_{r}+I_{\text {in }}+N P
$$

де $I_{p}-$ оціночний показник інвестиційного потенціалу регіону;

$I_{r}$ - оціночний показник рівня інвестиційних ризиків для бізнесу;

$I_{\text {in }}-$ обсяг реальних (як правило прямих) інвестицій;

NP - сумарна кількість збиткових (кризових) суб'єктів господарювання в регіоні.

В основу оцінки регіональних конкурентних переваг, слід ввести чинники ціноутворення, в зв'язку з чим показники оцінки рівня життя в регіоні розглядаються з точки зору їхнього впливу на регіональний попит і пропозицію. На думку автора, населення регіону не повинно розглядатися тільки як суб'єкт регіонального ринку праці та носій купівельної спроможності. Рівень і якість життя населення в регіоні повинні бути метою розвитку і головним критерієм регіональної конкурентоспроможності.

Слід зазначити, що у всіх вищевикладених методиках оцінки регіональної конкурентоспроможності рівень життя населення в регіоні розглядається не як критерій, а як засіб економічного зростання, і, відповідно, результуючим показником по зазначений групі індикаторів має бути валовий регіональний продукт на 1 чол.

Таким чином, показники рівня життя в регіоні повинні відображати, перш за все, рівень розви- тку людського потенціалу та стан галузей соціальної інфрраструктури. Зважаючи на вищенаведене представляє інтерес використання при оцінці конкурентних позицій регіону індексу розвитку людського потенціалу. Наприкінці XX ст., групою фрахівців Організації об'єднаних націй, була розроблена методика оцінки рівня розвитку людського потенціалу, в якій на перше місце було поставлено не здатність до продуктивної праці (тобто економічна цінність людини), а фрактор всебічного розвиток людини через розширення можливостей вибору завдяки зростанню тривалості життя, якості освіти та рівня фрактичних доходів. Фактор людського розвитку почав розглядатися як стратегічна мета глобального суспільного прогресу, а не як інструмент для економічного зростання [7].

При розрахунку індексу доходу для регіонів України можуть вводиться додаткові умови [3]:

- коригування (пропорційне збільшення) валового регіонального продукту (ВРП) кожного регіону на що не розподіляється частина ВВП країни;

- коригування ВРП на різницю в цінах шляхом множення на дельту прожиткового мінімуму до прожиткового мінімуму в регіоні;

- перерахунок за паритетом купівельної спроможності (ПКС) для певного року.

Таким чином, автором пропонується варіант розрахунку регіональних конкурентних переваг, доповнений показниками щодо розвитку людського потенціалу та стану соціальної інфрраструктури регіону. Комплексний показник регіональних конкурентних переваг має утворюватися $з$ двох складових:

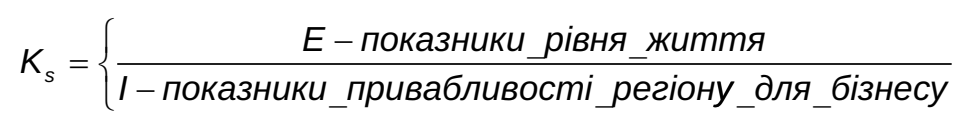

Відповідно кожен з них включає в себе:

$$
E=H_{d e v}++U_{l}+A+D
$$

де $H_{\text {dev }}$ - індекс розвитку людського потенціалу окремого регіону; $G$ - коефріцієнт Джині; $U_{l}$ - рівень регіонального безробіття; $A$ - площа житлових приміщень на 1 чол.; $D$ - забезпеченість населення медичними працівниками.

Агрегований показник I - інвестиційної привабливості регіону визначається за фрормулою (4).

Методика будується на процедурі ранжирування регіонів за оціночним значенням кожного з приватних показників з визначенням відповідного місця регіону. Розрахунок інтегрального показника проводиться поетапно шляхом реалізації наступним шляхом. Так на першому етапі по кожному з оціночних індикаторів визна- чається ранг кожного регіону починаючи 3 кращого значення (перше місце) і закінчуючи гіршим значенням (останнє місце). Потім отримані ранги підсумовуються і визначаються інтегровані ранги за показником рівня життя населення та показником привабливості регіону для бізнесу. Регіон, який набрав меншу кількість балів, вважається більш конкурентоспроможним.

Згідно з цією методикою, головними складовими інвестиційного клімату є: Інвестиційний потенціал як сума об'єктивних передумов для есрективного вкладення інвестицій, що залежать від наявності та різноманітності ссрер та об'єктів інвестування. Інвестиційний ризик як ймовірність втрати інвестицій або отримання доходу від них. При цьому показ- 
ники інвестиційного потенціалу та інвестиційного ризику $\epsilon$ характеристикою передумов і можливостей розвитку регіону [5].

Інтегральний ризик складається 3 наступних видів ризику: законодавчий (сукупність правових норм, що регулюють економічні відносини на території); фрінансовий (напруженість регіональних бюджетів і сукупні фрінансові результати діяльності підприємств регіонів); економічний (тенденції в економічному розвитку регіону); політичний (політичні вподобання населення); соціальний (рівень соціальної напруженості); екологічний (рівень забруднення навколишнього середовища); кримінальний (рівень злочинності в регіоні з урахуванням тяжкості злочинів). Ранг регіону за кожним видом ризику визначався виходячи із значення індексу інвестиційного ризику - відносного відхилення від національного рівня, який приймається за одиницю.

Сукупний інвестиційний потенціал регіону складається з ряду приватних потенціалів, кожен з яких, в свою чергу, характеризується цілою групою показників: ресурсно-сировинного (середньозважена забезпеченість балансовими запасами основних видів природних ресурсів); виробничого (сукупний результат господарської діяльності населення в регіоні); споживчого (сукупна купівельна спроможність населення регіону); інсрраструктурного (економіко-територіальне положення щодо головних транспортних комунікацій і його інфрраструктурна облаштованість, інтенсивність проникнення Інтернету і поширеність мобільного зв'язку); трудового (чисельність економічно активного населення і його освітній рівень); фрінансового (загальна сума податкових та інших грошових надходжень в місцеві бюджети); інституційного (ступінь розвитку провідних регіональних інститутів розвитку економіки); інноваційного (рівень впровадження технологій в регіоні) $[1 ; 6]$.

Ранг кожного регіону за кожним визначеним видом потенціалу залежить від кількісної оцінки величини цього потенціалу, як частки (у відсотках) в сумарному потенціалі всіх регіонів України. Виходячи з вищевикладеного, автор пропонує наступний алгоритм оцінки регіональних конкурентних переваг (рис. 1).

Хоча сьогодні населення, стає одним 3 найважливіших ресурсів регіонального розвитку, а рівень життя населення $€$ одним з основних показників регіональних конкурентних переваг, в більшості представлених в даний час методиках оцінки регіональної конкурентоспроможності рівень життя населення в регіоні розглядається тільки як засіб економічного зростання, і, відповідно, результуючим показником по окресленій групі індикаторів має стати саме показник валового регіонального продукту в розрахунку на 1 чол.

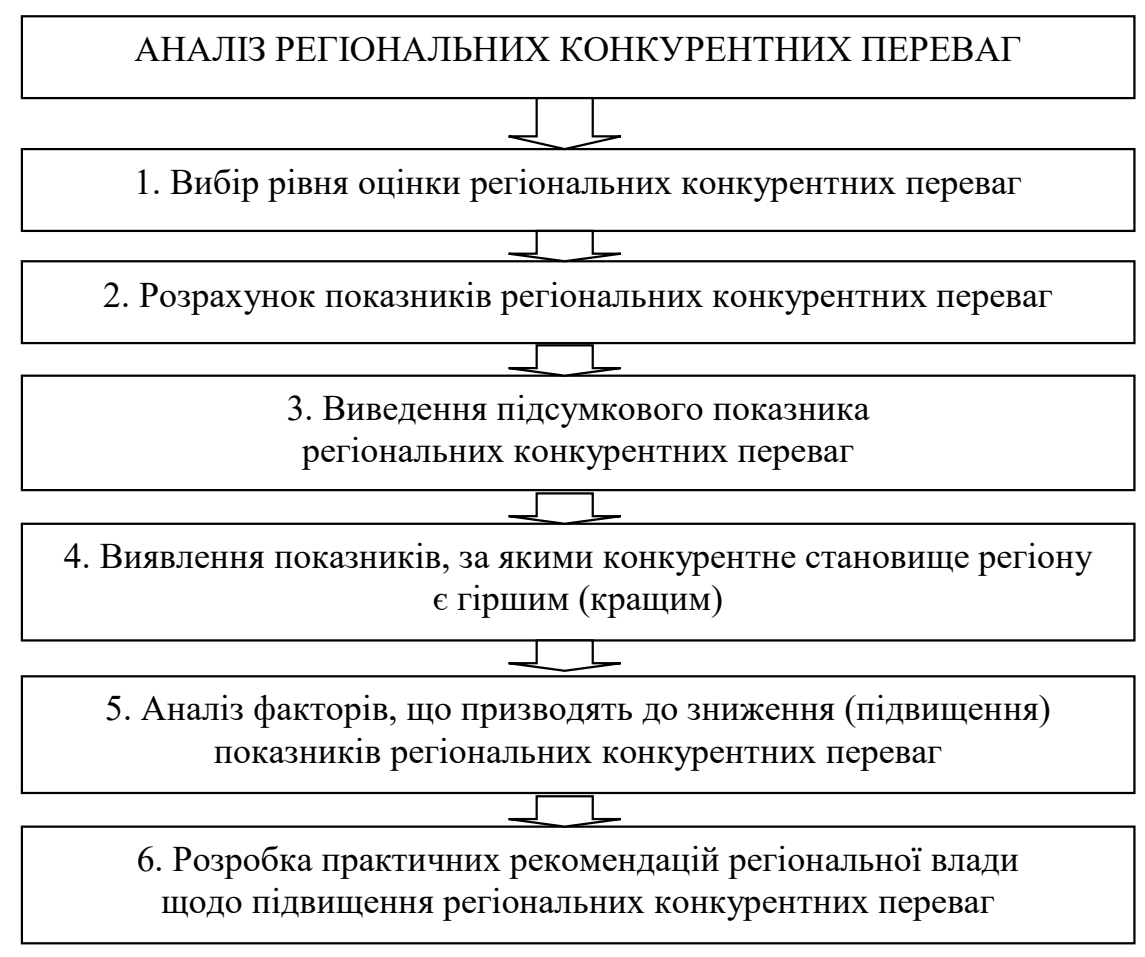

Рис. 1. Алгоритм оцінки регіональних конкурентних переваг 
Висновки. В межах завдання формування регіональних конкурентних переваг це поняття ми визначаємо як здатність створювати умови для сталого розвитку регіону, виражена через рівень (якість) життя населення і ефективність використання наявних ресурсів в умовах вільного і справедливого ринку. Об'єктивною основою економічної цілісності регіону є його територіально-виробничий комплекс.

Визначено, що для управління економічними процесами на регіональному рівні велике значення має оцінка конкурентних позицій регіонів. Питання оцінки конкурентних позицій регіонів ставилося в економічній літературі неодноразово, проте до теперішнього часу він залишається відкритим. Було доведено, що методи оцінки регіональних конкурентних переваг, що будуються тільки на даних статистики, мають, на один головний недолік - неможливість оцінити потенціал розвитку економіки. Було запропоновано модель розрахунку регіональних конкурентних переваг, яку доповнено показниками щодо розвитку людського потенціалу та стану соціальної інфрраструктури регіону. Комплексний показник регіональних конкурентних переваг складається з двох складових: рівень життя населення та інвестиційна привабливості регіону.

\section{СПИСОК ВИКОРИСТАНИХ ДЖЕРЕЛ:}

1. Забезпечення конкурентоспроможності регіонів у контексті активізації економічного розвитку / О.Ю. Бобровська, Т.О. Савостенко, І.Е. Польська [та ін.]; за заг. ред. О.Ю. Бобровської. Дніпропетровськ : ДРІДУ НАДУ, 2013. 248 с.

2. Boschma R. Competitiveness of Regions from an Evolutionary Perspective. Regional Studies. 2004. № 38(9). 1001-1014.

3. Романко О.П. Формування стратегії есрективного управління конкурентоспроможністю регіону. Причорноморські економічні студії. 2019. № 39(2). С. 48-51.

4. Perry M. Finding Space for the Creative Class: AReview of the Issues. Regional Policy and Practice. 2011. 29(1). 325-341.

5. Захарченко С.В. Научно-методические основы оценки конкурентоспособности регионов Украины в национальном и международном измерении при формировании инновационной модели развития. Украина и ее регионы на пути к инновационному обществу : монография в 4 т. / под общ. ред. В.И. Дубницкого, И.П. Булева. Донецк : Юго-Восток, 2011. Т. 2. С. 103-139.

6. Павліха Н.В., Кицюк І.В. Управління конкурентоспроможністю національної економіки: регіональний вимір : монографія. Східноєвропейський національний університет імені Лесі Українки. Луцьк : Вежа-Друк, 2014. 184 с.

7. Rowe James E., McLaren Don. Exploring competitive advantage in a regional community context. Australasian Journal of Regional Studies. 2017. Vol. 23. No. 2. 152-173.

8. Turok I. Cities, Regions and Competitiveness. Regional Studies. 2004. 38(9). 1061-1075.

\section{REFERENCES:}

1. Zabezpechennya konkurentospromozhnosti rehioniv u konteksti aktyvizatsiyi ekonomichnoho rozvytku [Ensuring the competitiveness of regions in the context of activating economic development] / O.Y. Bobrovs'ka, T.O. Savostenko, I.E. Pol's'ka [ta in.]; edit. O.Y. Bobrovs'koyi. Dnipropetrovs'k: DRIDU NADU, 2013. 248 p. (in Ukrainian)

2. BoschmaR. (2004) Competitiveness of Regions froman Evolutionary Perspective. Regional Studies, 38(9), pp. 1001-1014.

3. Romanko O.P. (2019) Formuvannya stratehiyi efektyvnoho upravlinnya konkurentospromozhnistyu rehionu. [Formation of a strategy for effective management of the region's competitiveness]. Black Sea Economic Studies, 39(2), pp. 48-51. (in Ukrainian)

4. Perry M. (2011) Finding Space for the Creative Class: A Review of the Issues. Regional Policy and Practice, 29(1), pp. 325-341.

5. Zakharchenko S.V. (2011) Nauchno-metodicheskiye osnovy otsenki konkurentosposobnosti regionov Ukrainy v natsional'nom i mezhdunarodnom izmerenii pri formirovanii innovatsionnoy modeli razvitiya [Scientificallymethodical bases of an estimation of competitiveness of Ukrainian regions in the national and international dimension in the formation of an innovative model of development]. In V.I. Dubnitskiy, \& I.P. Bulev (Eds.). Ukraina i yeye regiony na puti $\mathrm{k}$ innovatsionnomu obshchestvu [Ukraine and its regions on the way to an innovative society] (Vols. 1-4): vol. 2, pp. 96-121. Donetsk: South-East. (in Ukrainian)

6. Pavliha N.V., \& Kytsyuk I.V. (2014) Upravlinnya konkurentospromozhnistyu natsional'noyi ekonomiky: rehional'nyy vymir [Managing of the national economy competitiveness: the regional dimension]. Lutsk: Lesya Ukrainka Eastern European National University. (in Ukrainian)

7. Rowe James E., McLaren Don. (2017) Exploring competitive advantage in a regional community context. Australasian Journal of Regional Studies, vol. 23, no. 2, pp. 152-173.

8. Turok I. (2004) Cities, Regions and Competitiveness. Regional Studies, 38(9), pp. 1061-1075. 